\title{
Posible al da lonja eremuan eskuartze soziohezitzaile bat aurrera eramatea? Trapagarango kasuaren azterketa
}

\section{Maialen García Valdizán}

Gizarte hezitzailea

Israel Alonso Sáez

Euskal Herriko Unibertsitatea (UPV/EHU)

<israel.alonso@ehu.eus>

\section{Naiara Berasategi Sancho}

Euskal Herriko Unibertsitatea (UPV/EHU)
Ikerketa honek Trapagarango udalerriko lonjen fenomenoa eta gazte lonjeroen parte-hartze mota, espazio horien barruan zein kanpoan, aztertu nahi du; gazte horiek euren berdinekiko zein komunitatearekiko duten harremana ezagutzeko. Lana metodologia kualitatiboan oinarritzen da, zehazki, ikuspegi komunikatibo kritikoan. Ikerketaren emaitzek erakusten dute lonjak gazteen bizitzetan erreferentziazko espazioak bilakatzeaz gain, kolektibo horren parte-hartzea bideratzeko alternatiba bat bihurtu direla.

\section{GAKO-HITZAK:}

Lonjak, eskuartze soziohezitzailea, Gizarte Hezkuntza, gazteen parte-hartzea, gazteen lokalak, ekintza komunitarioa.
La siguiente investigación trata de analizar el fenómeno de las lonjas en el municipio de Trápaga y la participación que los/as jóvenes llevan a cabo tanto dentro como fuera de estos locales. El trabajo tiene una fundamentación metodológica cualitativa, concretamente en la perspectiva comunicativa crítica. Los resultados de la investigación muestran que las lonjas no son sólo un lugar de referencia en la vida de los/las jóvenes, sino que también se han convertido en una alternativa para hacer posible la participación de este colectivo.

\section{Palabras Clave:}

Lonjas, intervención socioeducativa, educación social, participación juvenil, locales juveniles, acción comunitaria. 


\section{Sarrera}

Lonjetan edo lonja eremutik gauzatzen den partehartzea nolakoa den aztertzea du helburu lan honek, Trapagarango udalerriko kasua aztertuz. Gure gizartean espazio hori gazteentzat gune garrantzitsu bihurtzen ari da, haien berdinekoekin modu intimoago batean elkartzeko leku bilakatuz. Komunitateak espazio horren inguruan begirada negatiboak izateko joera dauka, gazteak lonjen barnean egiten dituzten ekintzen inguruan mesfidantza eta ardura erakutsiz. Fenomeno horren inguruan ikerketa gutxi gauzatu dira eta, hori dela eta, sozializazio espazio horren inguruko informazio askorik ez dago; horien errealitatea zein den ezagutzeko aukera gutxi egonez. Testuinguru horren aurrean, beharrezkoa dirudi, errealitatea nolakoa den aztertzea, baina horretarako ezinbestekoa izango da espazio horiek nolakoak diren jakitea, gazteak egiten dituzten jarduerak ezagutzea, ekintza soziohezitzaile gisa espazio horiek ematen dituzten aukeren berri izatea..., beti ere, ikuspegi guztien ahotsak jasoz.

Kasu azterketa hau, Gizarte Hezkuntzako Behaketa/ Kontseilu-ak eta Bizkaiko Foru Aldundiko Gazteriaren Saileko teknikoak, Susterra fundazioko hezitzaileak, Euskal Herriko Unibertsitateko irakasleak eta ikasleak parte hartzen duten 'Las prácticas de éxito en participación y crecimiento juvenil en lonjas en Bizkaia'1 ikerketaren barnean kokatzen da.

\section{Lonjen fenomenoa}

\subsection{Lonjen bilakaera eta egungo egoera}

Lonja aisiarekin lotutako gazteen fenomeno gisa asko hedatu da azken urteotan. Hala ere, gure ingurunean partekatutako espazio batean batzartzeko tradizio hau ez da zerbait berria. Kirol-lagunarteak, sozietate gastronomikoak, izaera ezberdinetako klubak (mendizaleak, xakekoak, ziklismokoak...) eta elkarteak denbora librearen antolaketa itxuratu dute XIX. mendetik eta XX. mendean zehar.

Denboraren poderioz gaueko aisialdia garatzen joan da eta 9o. hamarkadan disko tabernak eta makro diskotekak agertzen dira. Garai honetan klubak eta afterrak ere azaltzen dira ordutegi hedatuago batekin. Horiez gain, festa auto-antolatuak eta erdi

${ }^{1}$ Ikerta hau martxan dago eta 2016an bukatuko da. Ikerketaren helburu batzuk honakoak dira: 1) gazte-parteen hartzea lonja eremuan nolakoa den aztertzea; 2) lonjetako bidelaguntzako praktiken indarguneak eta oztopoak identifikatzea; 3) lonja eremuan gazteen parte-hartzea ahalibidetzen duten indikidoreak zehaztea. Horiez gain, ikerketaren beste helburu bat da, arlo honetan parte-hartzeko eta eskuartze soziohezitzailea bultzateko arrakasta praktika gida bat plazaratzea. Helburu horiek aurrera eramateko, ikerketa taldean UPVEHUko Leioako Gizarte Hezkuntza Graduko ikasleak eta irakasleak, Susterrako hezitzaileak eta Bizkaiko Foru Aldundiko teknikoak parte hartzen ari dira. Hala, Bizkaian, lonjan arloan, aurrera eramaten ari diren esperientzia eta kasu batzuk aztertzen ari dira; hain zuzen ere, Santurtzi, Bermeo, Galdakao eta artikulu honetan analizatzen den Trapagarango kasua. klandestinoak garatzen hasten dira hiri-erdigunetik kanpo gaueko aisialdiarekin erlazioa duten erregulazio administratibo eta orden legaletatik ihes egiteko asmoz. Kontrolpetik kanpo egoteko nahia agertzen da intimitatearen bila.

Gainera, 90. hamarkadan hiri batzuetan lokalen ordutegiak erregulatzen hasten dira eta adingabeen kasuan alkoholaren salmenta kontrolatzen hasten da. Guzti honek, "botellón” deritzon fenomenoaren sorkuntzari harrera ematen dio. 1980 eta 1990.urteetaik aurrera gazteek espazio publikoak alkoholaren kontsumoa gauzatzeko okupatzen dituzte. Hau ohiko praktika bihurtzen da eta kolektibo horri inguratzen dion gainerako aisialdiarekin bezala ere kuestionatu egiten da arazo sozial moduan definituz. Hori dela eta, administrazio eta udalerri ezberdinak espazio publikoaren erabilera neutralizatzen saiatzen dira (Tejerina, Carbajo eta Martínez, 2012). Egoera horren aurrean, eta alternatiba berrien bila, gazteak 70 eta 80 .urteetako lokalak (lehen batzartzeko erabiltzen ziren garajeak, ganbarak eta edozein motatako espazio posibleak) haienak egin eta fenomeno berri bati ongietorria ematen diote: lonjei, alegia (Laespada et al., 2008).

Fenomeno berri hau 9o.hamarkadan detektatu egiten da, baina duela 4-5 urte fenomeno masibo moduan zabaltzen da, aipatu bezala, gazteak erabilerarik gabeko espazioak haien denbora librea betetzeko tokiak bihurtuz.

Azken urteotan gazteek eta nerabeek aurkako giroa topatu dute kalean. Adingabeak alkoholaren kontsumotik aldentzeko ekimenak (hala nola adingabeei alkohola saltzea debekatzeak edo litroak egin ez ditzaten hartutako neurri berriagoek) espazio publikoaren erabilera murriztu dute; horren ondorioz, gazteenek lokaletan bilatu dute babesa, aisiaz gurasoen begiradatik urruti gozatu ahal izateko.

Alkoholaren eta beste substantzia batzuen kontsumoekin lotutako arautzeek neurri batean azaltzen dute lonjek nerabeen artean duten zabalkundea, eta emantzipazio adina atzeratu izana, bestalde, lagungarria izan daiteke zaharragoen artean ere zergatik zabaldu diren azaltzeko. Haiei toki propio bat, partekatua bada ere, edukitzeko aukera ematen diete lonjek, familia-etxetik kanpo. Horrenbestez, lonja erdibidean dago gurasoen gelaren eta gazteek, batez beste, 30 urte egin arte lortzen ez duten etxebizitzaren artean.

Gure inguruan, azken urteotan, lonjen fenomeno hau ugarituz eta finkatuz joan da, 15 eta 29 urte bitarteko gazteen bizitzan paper garrantzitsu bat jokatuz. Euskadiko gazteen \%2ok lonja bat daukate; 62.000 gazte inguruk alegia. Egun lonjarik ez badute ere, gazteen \%25ek noizbait lonja bat izan dute eta gainerako \%55ek ez dute inoiz lonja edo lokalik izan (Corcuera, Bilbao eta Longo, 2013). Lonjen erabilera batez ere 15-30 urte bitartean ematen da, eta 15-24 urte bitarteko gazteak dira espazio horiek gehien erabiltzen dituztenak. 
Lokal horietan dauden gazteen perfilari dagokionez, gehienak 25 urtetik beherakoak dira, mutilen presentzia neskena baino handiagoa da, gehiengoak ikasleak dira eta ia guztiak haien jatorrizko familiekin bizi dira. Beraz, esan daiteke Euskadin lonja bat duten gazteen profila honako hau dela: mutila, 21 urtekoa, lehen lokala 17 urte eta erdi zituenean izan zuena, ikaslea eta gurasoen etxean bizi dena (Corcuera, Bilbao eta Longo, 2013).

Bestalde, lonja gehienak mistoak (\%69) dira, eta kide kopurua handia izaten da. la erdiak (\%49) 20 kide baino gehiago ditu eta \%15ak zoetik gora. Erabilpenari dagokionez, asteburuetan ematen dute gazteek bertan denbora gehien.

Ikusten denez, koadrila baten edo gehiagoren erreferentziazko eta bizikidetzako esparrua da lonja. Horietara toki propio bat edukitzeko, helduen kontrolpetik kanpo eta klima txarretik babestuta egoteko, eta aisia tabernetan bezain garestia ez delako joaten dira batez ere (ibidem).

\subsection{Lonjak parte-hartzeko esparru bezala}

Parte-hartzea giza eskubideei lotuta dago eta edozein pertsonak gizartearen xede politiko, ekonomiko, sozial eta kulturalen erabakietan eta gauzatzean eskuartzeko daukan eskubidea aldarrikatzen du. Gainera, giza garapenerako jarduera garrantzitsua kontsideratzen da. Parte-hartzea konpromiso modu bat da, bai pertsonalki baita kolektiboki ere. Errespontsabilitateak eta eskubideak ditu berekin. Amnistia Internazionalek honela definitzen du:

Es aquello que permite en mayor medida que cada miembro del grupo despliegue sus atributos y potencialidades individuales y haga aportes decisivos a la vida en conjunto (1996: 9).

Gazteen parte-hartzearen inguruan hitz egitean eragiten dieten erabakietan ahotsa izateari erreferentzia egiten zaio. Horren bidez, eragile aktiboak bihurtzen dira eta ezagutza ezberdinak bereganatzen dituzte heldutasun bat hartuz. Hau da, ikaskuntza eta hezkuntza modu bat da (Canadian Mental Health Association, 2003). Azken finean, aspektu ezberdinetan haien inplikazioa, konpromisoa, parte-hartzea eta elkarlana ematen dira eta guzti horrek abilezia ezberdinak garatzea ekartzen die, aipatutako heldutasunaz gain autonomoagoak bihurtuz. Esan daiteke, gazteen parte-hartzeak kolektibo horrek dituen interesen, gaitasunen eta sendotasunen errekonozimendua inplikatzen duela. Gaur egun gazteak dauzkaten parte-hartzeko moduak dira (Reverte, 2009):

- Parte-hartze instituzionalizatua: Botere publikoak sustatzen dituen mekanismo eta jarduera multzoa $\mathrm{da}$, zeinak herritarren parte-hartzea bultzatu errazten duten politika publikoetan eta erabaki politikoetan eragiteko. Adibidez, partidu politiko baten parte izatea.
- Parte-hartze antolatua: Negozio, profesio edota lanbide berean aritzen diren interes komunak dituzten pertsonek osatzen dituzten elkarteak dira. Hauen helburua kideen arteko laguntza garatzea da. Adibidez: ikasle edo gurasoen elkarteak.

- Parte-hartze alternatiboa: Parte-hartze mota honetan mugimendu sozialen presentzia agertzen da. Horiek, eremu soziopolitikora bideratuta dauden indibiduo edo erakunde talde ez organizatuak dira eta helburu moduan aldaketa soziala daukate. Adibidez: mugimendu feminista edota ikasle edo langile mugimendua.

- Parte-hartze solidarioa: Kasu honetan boluntariotzaren inguruan ari gara. Hau da, modu libre batean (egindako lanagatik ezer kobratu gabe) komunitateari zerbitzua eskaintzeari zaio. Boluntarioak bazterketa soziala pairatzen dituzten kolektiboei zuzendutako proiektuetan partehartzen dute.

- Parte-hartze ez formala: Parte-hartze mota honetan auzo edo herriko bizitzaren parte izan eta horretan parte hartu nahi duten pertsona taldeak (auzokideak, ikasleak, lagunen kolektiboak...) sartzen dira zeinak entitate edo elkarte moduan osatzen ez diren.

Gazteen parte-hartzearekin jarraituz, euskal komunitatean 2013an aurrera eramandako ikerketa batean (González López, 2013) gazteei partehartzera eramaten dieten motibazioen artean, talde baten parte izatearen nahiak garrantzia nabarmena hartzen du. Berria eta ezezagunaren indarrak ere agente motibatzaile moduan jarduten du, batez ere ezinegonak dituzten gazteen artean. Horrez gain, familiek ere guzti horretan eragin handia izaten dute, gune horretan esperientzia parte-hartzaile baten presentziak partizipazioa emateko probabilitatea igoz. Batez ere bizi izandako esperientzia hori positiboa denean. Horiez gain, koste ekonomiko altua suposatzen duten jardueren alternatiba bat izateak ere parte-hartzeko motibazio agenteak dira.

Dena den, eta nahiz eta parte-hartzeak motibazio ezberdinak sortu, ezagutzen ez denaren aurreko beldurra edota denbora, interes eta motibazio faltak... gazteak parte-hartzetik aldentzeko arrazoien artean kokatzen dira. Ikerketa honetan agerian uzten da nola, azken urteetan, gazteen parte-hartzearen jaitsiera bat eman den: Alegia \%40,6 mantetzen da, $\% 29 a n$ handitzen da eta \%30,4 jaisten da.

González López-ek (2013) hainbat proposamen luzatzen ditu gazteen parte hartzea sustatzeari begira, erreferentzia moduan hartuta, hona hemen aipatu ahal diren praktika on batzuk:

- Gazteei euren nahiak, interesak, iritziak eta proposamenak esateko aukera ematea.

- Partaide berriak zaintzea. Hau da, horien gaitasunak kontuan hartzea egokitutako eginkizunetan gustura egoteko. 
- Parte-hartzen ez dutenentzako espazioak irekitzea haiek ere entzunak izateko.

- Komunikazio kanpainak egitea parte-hartzearen inguruan, beldurrari aurre egiteko asmoz.

- Gazteen inguruan dagoen estereotipo negatiboak ekiditeko, kolektibo horren eskutik, txarla ezberdinen garapena.

- Gazte eta helduen artean dialogo intergenerazionala sortzea; bi kolektibo horien arteko interakzio egokia emateko.

- Gazteek egindako lana baloratzea.

- Aldaketak onartzea; horiek modu negatibo batean ikusi beharrean aukera moduan antzematea.

Lonjak gazteen espazio bihurtu dira, elkartzeko tokia. Horietan egoteak nagusien mundutik autonomia bat eskaintzen die. Hala, esan daiteke gazteak haien aisialdirako erabiltzen dituzten erabilera pribatuko lokalak direla, haiek izanez agintea dutenak.

Halaber, identitate pertsonal eta sozialaren eraikuntzan laguntzeaz gain, gazteek taldean duten partaidetza berresten dute eta haien harreman sozialak ere indartzen dituzte. Gainera, esan daiteke, bertan ikaskuntza prozesu bat ematen dela, errespontsabilitate ezberdinen onarpenarekin batera, eta hauei esker, ezagutza eta jakintza berrien barnerapena sortzen da gazteak autonomoagoak bihurtuz; izan ere, haiek dira erabakiak hartu, negoziazioak egin, bizikidetzarako eta funtzionamendurako arauak ezarri eta errespontsabilitateak aukeratu behar dituztenak (Laespada et al., 2008).

Laburbiltzearren, lonjak erlazio, babes eta intimitate espazioak dira eta taldearekin elkartzeko beharrari erantzuna ematen diote. Hala, partehartzea eta elkar harremanak ahalbidetzen duten guneak bihurtuz.

\subsection{Lonjak eta esperientzia soziohezitzaileak}

Gazteen lonjen fenomenoak, ia hasieratik, erakundeen arreta erakarri du, eta udal administrazioak bultzatu ditu gaiari buruzko lehen ikerketak. Zalantzarik gabe, era horretako lokalek batzuetan eragiten dituzten auzkokideen arteko gatazkek eta, agian neurri handiagoan, lokalak erabiltzeagatik edo alkohola edo drogak kontsumitzeagatik gerta litezkeen istripuek ekar ditzaketen segurtasun-arazoei aurrea hartzeko gogoak aisia-gune horien erabiltzaileekin harremanetan jarri nahi izatea eragin dute.

Udalen gazteria-zerbitzuek edo droga-mendetasunen prebentzio-zerbitzuek agindu dituzte orain arte egindako azterlanak, haien funtzionamendua ezagutzeko, lokalen erabiltzaileen beharrak diagnostikatzeko eta auzokideekin izan litzaketen arazoak zuzenean jakiteko. Metodologia kualitatiboa erabili dute kasu guztietan (elkarrizketak eta lokaletara bisitak egin dituzte), eta bitartekotzako edo arriskuak prebenitzeko programak ezarri dituzte.
Tokiko adminsitrazioak gaiarekiko interesarekin batera, Gazteen Euskal Behatokiak ere agertu du lonjekiko interesa nerabeekin eta gazteekin lan hezigarria egiteko esparru gisa. Aisialdi hezigarriaren arloan lan egiten duten erakunde eta taldeentzat lonjak esparru ezin hobeak dira eskuartzeko, horien bitartez gazteengana modu naturalagoan iristen baitira (Corcuera et al., 2013).

Euskal Herrian instituzio ezberdinetatik (gehienbat udaletatik) lonjei begira bideratu diren eskuartzeak gehienetan izaera arauemaile eta zigortzailea izan dute. Baina, azken urteotan aldaketak ikusten ari dira, eta eskuartze soziohezitailearen protagonismoa handitzen ari da. Jarraian aurkezten den 1. Taulan ikus daiteke, azken urteetan, Euskal herriko herri desberdintan bideratu diren zenbait esperientzia. Hala, esperientzia horien inguruko laburpena eta esperientzia horietan parte-hartzea nola bideratu den jasotzen da.

Taulan agertzen diren esperientzietan ikus daiteke, oro har, aldaketa bat ematen dela eta esperientzia gehienek ikuspegi sozio-hezitzaile bat bereganatzen dutela. Bestelde, esan daiteke nolabaiteko saiakera bat egiten ari dela proiektu parte-hartzaileak bideratzeko eta komunitatea prozesuan inplikatzeko. Esperientzia horiez gain, bada beste esperientzia bat Trapagan aurrera eramaten ari dena, Trapagazte izenekoa eta hurrengo atalean jasotzen da esperientzia horren inguruko informazioa.

\subsection{Trapagarango esperientzia}

Trapagaran ${ }^{2}$ herrian lonjetan bideratu den aisiari eta parte-hartzeari dagokionez bi ekimenen presentzia aipatu daiteke: alde batetik, gazteak modu autogestionatu batean duela 8 urte sortu zuten Lonjero Egunaren ospakizuna; bestetik, duela 4 urte Trapagazte izeneko programa. Programa hori udaletxearen eskutik martxan jarri zen, bertan gazteek dituzten beharrak kontuan hartzen saiatzen dira eta jarduera desberdinak antolatu dituzte haien beharrak kontuan izanda.

Lonjero Eguna, modu autogestionatu batean gazteek duela 8 urte sortutako ospakizun bat da. Ekimen hori Trapagarango San Gabriel auzoan ospatzen da eta bertan lonjeroak eta lonjarik ez dituztenak elkartzen dira goizetik gauerarte, ekintza desberdinetan (futbol txapalketa, herri bazkaria, poteoa, kontzertuak...) parte hartuz.

Ospakizun hori aurrera eraman aurretik lonjen artean ez zen elkartasun handirik somatzen. Baina lokal hauek eskaintzen zuten komunikazio zubia aprobetxatuz, eta San Gabrielgo jaiak arrakasta handirik ez zutela ikusita, Gaztetxeko hainbat kide ospakizun bat egitearen proposamena zabaldu zuten;

2 Trapagaran Bizkaiko herri bat da meatzaldeko eskualdean kokatuta dagoena. 2012ko erroldaren arabera, 12.189 pertsona bizi dira bertan. 


\begin{tabular}{|c|c|c|}
\hline & Proiektuaren laburpena & Parte-hartzearekin duen lotura \\
\hline $\begin{array}{l}\text { Txorierriko mankomunitatea } \\
\text { (Bizkaia) [Quintana et al., } \\
\text { 2013] }\end{array}$ & $\begin{array}{l}\text { Txorierriko mankomunitatean, konkretuki } \\
\text { Sondikako udalerrian lonjeroekin komunikazio eta } \\
\text { bitartekaritza lana aurrera eraman da; fenomeno } \\
\text { hori erregulatzeko ordenantza bat egin da. }\end{array}$ & $\begin{array}{l}\text { Sondikan aurrera eramandako ordenantza lantzeko } \\
\text { gazteen partehartzea eskatu da. Horretarako, gazte } \\
\text { horien iritziak eta proposamenak jaso dira. }\end{array}$ \\
\hline $\begin{array}{l}\text { Atetik Atera (Zalla, Bizkaia) } \\
\text { [Universidad del País } \\
\text { Vasco / Euskal Herriko } \\
\text { Unibertsitatea, 2012] }\end{array}$ & $\begin{array}{l}\text { Lonjeroei bideratutako prozesu parte-hartzaile bat } \\
\text { martxan jarri da, horren asmoa auzokideekin eman } \\
\text { ahal diren gatazkei aurre egitea delarik. } \\
\text { Prozesu horrekin, lokal horiek erregulatzen dituzten } \\
\text { ordenantza mugatzaileak saihestea bilatzen da. }\end{array}$ & $\begin{array}{l}\text { Aurrera eramandako prozesu parte-hartzaile horretan } \\
\text { gazteen partaidetza elkarrizketen bidez bideratu da. } \\
\text { Herrian gauzatutako dinamika desberdinetan ere lonja } \\
\text { batzuen kolaborazioa eman da. }\end{array}$ \\
\hline $\begin{array}{l}\text { Programa Gazte Zabalik } \\
\text { (Santurtzi, Bizkaia) } \\
\text { [Susterra Federazioa, 2013] }\end{array}$ & $\begin{array}{l}\text { Susterra Federazioak, Bizkaiko Foru Aldundiko } \\
\text { Kirolaren eta Gazte Sailaren laguntzarekin joera } \\
\text { sozio-hezitzailedun proiektu bat gauzatu du, gazte } \\
\text { lonjeroekin kontaktu zuzen bat bilatuz. Horren } \\
\text { helburua gazteen parte-hartze eta promozio } \\
\text { programa bat planifikatzea, inplementatzea } \\
\text { eta ebaluatzea da. Proiektu hori } 15 \text { urtetik } 30 \\
\text { urterarteko Euskadiko gazteengana zuzenduta } \\
\text { dago. }\end{array}$ & $\begin{array}{l}\text { Gazteen aktibazio pertsonal eta parte-hartze soziala } \\
\text { bilatu da proiektu honetan, hala, gazteei interesatzen } \\
\text { eta eragiten dieten eremu ezberdinetan lan egin da. } \\
\text { Bestalde, euren gizarteratzea eta emantzipazioa } \\
\text { ahalbidetzeko ekintza desberdinak aurrera eraman } \\
\text { dira. Hori posible egiteko, bi hezitzaile herriko lonja } \\
\text { desberdinekin lan egiten dute. Bi lokalero topaketa } \\
\text { (lonjen arteko topaketak) egin dira jada, herriko lonjen } \\
\text { artean erlazio bat emanez. }\end{array}$ \\
\hline $\begin{array}{l}\text { Las lonjas ¿una } \\
\text { participación ciudadana } \\
\text { efectiva? La experiencia } \\
\text { de Portugalete (Bizkaia) } \\
\text { [Laespada et al., 2008] }\end{array}$ & $\begin{array}{l}\text { Portugaleten aurrera eramandako esperientzian } \\
\text { Trapagazte izenekoan lonjen fenomenoa aztertzeko } \\
\text { komunitatea osatzen dituzten agente ezberdinak } \\
\text { (gurasoak, gazte lonjeroak, auzokideak eta lonjen } \\
\text { jabeak) kontuan hartu dira. } \\
\text { Agente ezberdinek lokal horien inguruan dituzten } \\
\text { iritziak ezagutzeko aukera eman da, bakoitzak } \\
\text { fenomeno berri hori ulertzeko duen modua ezagutu } \\
\text { nahi izan delarik. }\end{array}$ & $\begin{array}{l}\text { Komunitatearen begiradak jasotzeko elkarrizketa } \\
\text { desberdinak burutu dira komunitateko agente } \\
\text { guztiekin. Hala, egindako elkarrizketetan ez da } \\
\text { soilik gazte lonjeroen parte-hartzea eman, baizik } \\
\text { eta komunitatea osatzen duten agente desberdinen } \\
\text { partehartzea bultzatu da. }\end{array}$ \\
\hline
\end{tabular}

Iturria: Egileak osatua.

Taula 2. Trapagarango lonjen inguruan egindako prozesu parte-hartzailearen ondorioak

\begin{tabular}{|c|c|}
\hline Zer da & $\begin{array}{l}\text { Trapagaranen aurrera eramandako prozesu parte-hartzaile baten emaitza: lonjen erabilera erregulatzeko gazteen } \\
\text { aisialdi espazio moduan. }\end{array}$ \\
\hline Helburua & $\begin{array}{l}\text { Konpromisoak lortzea eta lonjen erabiltzaileen, jabeen eta auzokideen arteko bizikidetza egokia lortzeko } \\
\text { oinarriak ezartzea. }\end{array}$ \\
\hline Metodologia & $\begin{array}{l}\text { - Antzeko esperientziak bizi izan dituzten udalerri ezberdinei buruzko informazioa jaso dira, horren analisia } \\
\text { egiteko. } \\
\text { - Lonjen kideekin, jabeekin eta auzokideekin topaketa batzuk burutu dira prozesuaren azaltzeko, tailer } \\
\text { ezberdinak eginez. Modu honetan, aipatutako kolektiboen ahotsak eta iritziak ezagutzeko aukera eman da. }\end{array}$ \\
\hline Emaitzak & $\begin{array}{l}\text { - Jabeei dagokionez, auzokideak modu desegokian haiengana joaten direla adierazten dute lonjako kideekin } \\
\text { arazo bat ematen denean. } \\
\text { - Auzokideak negatiboak agertzen dira lonjen gaiaren inguruan konponbide zorrotzak (ordenantza zorrotza, } \\
\text { lonjen itxiera...) proposatuz. } \\
\text { - Azkenik, lonjeroak inolako arazorik existitzen ez dela eta udalerriko lonjen artean harreman bat dagoela } \\
\text { aipatzen dute. }\end{array}$ \\
\hline Hartutako neurriak & $\begin{array}{l}\text { - Prozesu parte-hartzaile honetatik lortutako informazioaren ondorioz, lan egiteko puntu batzuk (zaratarekin } \\
\text { ematen diren arazoak konpontzea, lonjen segurtasun eta osasungarritasun egoerak hobetzea...) identifikatu } \\
\text { dira. } \\
\text { - Emaitza moduan ordenantza bat proposatzen da ondorengo gaiak erregulatu ahal izateko: segurua, kontratua, } \\
\text { zarata, higienea... }\end{array}$ \\
\hline
\end{tabular}

Iturria: Egileek osatua.

alde batetik, auzoaren jaiak berpizteko eta bestetik, gazteak elkartzeko eta batera zerbait antolatzeko. 2007 urtetik urtero ospatu da gazteen artean partehartzea oso handia izanez.

Lonjero Egunaren ospakizunetik 2012.urterarte lonjetan dauden eta ez dauden gazteekin ez da inolako eskuartzerik aurrera eraman, baina lonjekin emandako hainbat arazoen aurrean martxoaren 2012. urtean espazio horien erregulazioa posiblea izateko udaletxeak prozesu parte-hartzaile bat aurrera eramaten du lonjen jabe, auzokide eta lonjeroekin (Trapagarango Udala, 2012). Aipatutako prozesu honetatik ateratako ondorioen laburpena 2. Taulan jasotzen dira.

Egindako prozesu parte-hartzaile honetatik, eta Trapagarango gazteak komunitatean burutzen zuten parte-hartze eskasa eta haien aisialdia posible egiteko alternatiba gutxi zituztela ikusita, aurretik aipatutako Trapagazte programa sortzen da bi kontu horiei irtenbide bat eman nahian. 
Trapagazte Trapagarango udalerrian jaiotzen den programa $^{3}$ da zeinaren bitartez 16-32 urte bitarteko gazteengan ekintza ezberdinak burutzen diren gazteek adierazten dituzten beharrei erantzun bat emateko asmoz.

Trapagazte behin martxan jarrita gazte lonjeroekin beste prozesu parte-hartzaile bat abian jartzen da urriaren 2013an non gai konkretu batzuen inguruan gazteen iritziak batzen diren hauen arabera Trapagazte 2013-14 programa diseinatu ahal izateko.

Orain arte Trapagazte aisialdiaren ildotik egituratu izan da eta programaren dimentsioak zabaldu nahian, aurretik aipatu bezala, gai ezberdinen inguruan galdera ezberdinak egiten zaizkie lonjetako gazteei, hala, programak poliki-poliki bere edukia eta eskaintza osatuz (Trapagarango Udala, 2013). Hau da, hezkuntza zentzua hartuz. Hurrengo 3. Taulan prozesu horren laburpena ikus daiteke.

Taula 3. Trapagazteko parte-hartze herrritarra prozesuari buruzko txostena

\begin{tabular}{|c|c|}
\hline Helburua & $\begin{array}{l}\text { Prozesu parte-hartzaile baten bidez aisiaren, } \\
\text { kirolaren, kulturaren eta enpleguaren inguruan } \\
\text { Trapagako gazteek dituzten iritziak ezagutzea, } \\
\text { ondoren Trapagazte } 2013-14 \text { programa diseinatu } \\
\text { ahal izateko eta horrela gazteek dituzten beharrei } \\
\text { erantzun bat eman ahal izateko. }\end{array}$ \\
\hline Metodologia & $\begin{array}{l}\text { - Lonjetan batzartutako gazteei aipatutako } \\
\text { eremuen inguruko galdera irekiak dituen } \\
\text { formulario bat pasatzen zaie. } \\
\text { 3-5 egunetako marjina utzita pasatutako } \\
\text { formularioa jasotzen da eta gazteekin islatu } \\
\text { duten edukiaren inguruan hitz egiten da. }\end{array}$ \\
\hline Emaitzak & $\begin{array}{l}\text { - Orokorrean ezjakintasun handia adierazten } \\
\text { dute udalerriak aurretik aipatutako eremuen } \\
\text { inguruan dituen eskaintzei buruz. } \\
\text { - Irekiak agertzen dira proposamen berriak } \\
\text { emateko eta onartzeko. } \\
\text { - Herrian aldaketak egoteko gogoak adierazten } \\
\text { dituzte non haien iritziak, ideiak eta } \\
\text { proposamenak ezinbestekoak bilakatzen diren } \\
\text { leku garrantzitsu bat hartuz. } \\
\text { - Trapagazte programak presentzia handi hartzen } \\
\text { eta gazteen artean bere tokia irabazten ari } \\
\text { da. Aisialdi eremuan aipatzen den moduan, } \\
\text { programa hau monotoniatik ateratzeko } \\
\text { alternatiba bakarra izan dela azpimarratzen } \\
\text { dute batzuk. }\end{array}$ \\
\hline
\end{tabular}

Iturria: Egileek osatua.

3 Programa honen helburu nagusia gazteen aisialdiari erantzun bat ematea da, ondoko helburuak izanik:

- Gazteentzat (16-32 urte) zuzenduta dauden jarduera ezberdinak garatzea.

- Gazteen bizitzetan osasuntsuak diren ohiturak sustatzea edo mantentzea.

- Gazteen ezinegonak kontuan hartzea eta haientzat burutzen diren eskaintzen partaide egitea.

- Udalerriak duen eskaintza kulturalean gazteenak inplikatzea jarrera positiboak baloratzeko erremintak eskainiz.

Metodologiari dagokionez programa hau hezitzaile batek aurrera eramaten du. Berak kontaktua dauka lonja guztiekin hilean birritan bisitak eginez. Egonaldi hauetan batez ere gazteekin hitz egiteko aukera ematen da: berrien, jardueren edota berari auzokideen partetik heldu zaizkion kexak komentatzeko aukera emanez. Dena den, eta nahiz eta bisitak egiteko bi egun egon, bera Trapagarangoa denez eta udaleko beste zerbitzu batean lan egiten duenez herritik buelta bat ematen dagoenean eta lonja bat irekita ikusten duenean sartu egiten da bisitaldi hauetan denbora gehien eskainiz.
Prozesu parte-hartzaile honetan gazteek gogotsu parte hartu dute aldaketaren alde egiten duten proposamenak planteatuz. Gazteen proposatu dituzten jardueren artean, batzuk martxan jarri nahi dira: gaztetxokoa eta gazte gunea. Lehenengoak, 15 urteko gazteentzako bideratu da, gazte horiek elkartzeko gune berri bat sortuz; bigarrengoa, 17 urtetik gorako gazteei zuzenduta dago, lonjetan biltzen diren gazteez gain bestelako gazteen arteko elkar harremanak sustatzeko.

\section{Metodologia}

Trapagarango kasu azterketa hau, hasieran aipatu den bezala, lonjen inguruko ikerketa zabalago baten barruan kokatzen da. Ikerketa hau metodologia komunikatiboren bidez gauzatu da; horren bidez, eta berdintasunezko dialogo baten bitartez, zentzuaren sorkuntzara eta lantzen ari den errealitatearen transformaziora heltzen da (Flecha, Vargas eta Dávila, 2012). Beraz, berdintasunezko printzipioetan oinarrituz, metodologia4 horren bitartez ikertuak izan diren pertsonak prozesuaren parte aktibo bilakatzen dira. Ikuspegi metodologiko hau CREAk ${ }^{5}$ garatu izan du.

Artikulu honetan plazaratzen den kasu azterketaren metodologia oinarria kualitatiboa izan da. Hala, errealitatea aztertu egiten da bere testuinguru naturalean eta fenomenoak interpretatzen dira, inplikatuta dauden pertsonek horien inguruan dituzten esanahiak kontuan hartuz (Rodríguez, Gómez, Gil Flores eta García Jiménez, 1996; Flick, 2004).

Hauek dira ikerketaren helburuak:

- Trapagarango lonjen egoera aztertzea agente ezberdinen (gazte lonjeroak, hezitzaileak, teknikoak eta herriko elkarteak) begiradetatik.

- Trapagarango gazteak lonjetan duten partehartzea aztertzea agente ezberdinen (gazte lonjeroak, hezitzailea, teknikoak eta herriko elkarteak) begiradetatik.

- Trapagaranen aurrera eramaten den Trapagazte programa aztertzea eta programa horrek gazteengan ekarri duen inplikazioa eta partehartzea analizatzea.

- Ikerketa hau 2014eko urritik 2015 maiatzara arte aurrera eraman da eta erabilitako datuen analisirako teknikak hurrengoak izan dira:

4 Ikerketa metodologia horrek errealitatearen analisia prisma bikoitzetik egiten du: sistemen eta egituren inguruan batetik; eta giza agentziaren inguruan bestetik (Habermas, 1987; Giddens, 1995). Horretan, oinarrituta, zazpi printzipioak (Aubert, García y Racionero, 2009) osatzen dute metodologia komunikatibo kritikoa: 1) hizkuntza eta ekintzaren unibertsalitatea; 2) pertsonak subjetu eraldatzaile bezala; 3) arrazionaltasun komunikatiboa; 4) zentzu komuna; 5) hierarkia interpretatibo eza; 6) maila epistemologiko berdina; 7) ezagutza dialogikoa.

${ }_{5}^{5}$ Centro Especial de Investigación en Teorías y Prácticas Superadoras de Desigualdades (〈http://crea.ub.edu〉). 
- Dokumentuen analisia: Trapagako lonjari eta Gazte parte-hartzeari buruzko dokumentuak azteru dira.

- Elkarrizketak: galdera irekiez osatutako elkarrizketa erdi estrukturatuak erabili diraVargas, 2012). Guztira, 5 izan dira egindako elkarrizketak. Hiru elkarrizketan (2 neska eta mutil 1) lonjetan parte hartzen duten gazteek parte hartu dute. Bestalde, Trapagazteko hezitzailea eta Kultur saileko zinegotziak ere elkarrizkatuak izan dira. Elkarrizketen iraupena 35-40 minutukoa izan da.

- Talde eztabaida: Komunitateak ikerketa gaiaren inguruan duen ikuspuntua ezagutzeko asmoz, talde eztabaida bat aurrera eraman da komunitatearen barnean dauden agente ezberdinekin (merkatariak, erretiratuak eta AMPA). Guztira, 6 pertsonek parte hartu dute.

Datuen analisia burutzeko aurreko teknikak, parte-hartzaileen baimenarekin, grabatu eta transkribatu dira. Informazioaren azterketa egiteko, elkarrizketan parte hartu duten pertsonei kode bat egokitu zaie: Gazteen kasuan, G erabili da gazte izaera adierazteko, neska edo mutila den jaso da eta adina (Adibidez: G.N2.18.). Beste elkarrizketen kodeak dira: Hezitzailearena (E.Hz) Zinegotziarena (E.Z) eta Talde Eztabaida (TE.K). Aldez aurretik eraikitako sistema kategoriala oinarrituz transkripzio guztiak kategorizatu dira; analisia egiteko eta hortik emaitzak eta ondorioak plazaratzeko oinarria izanik.

\section{Emaitzak}

\subsection{Trapagarango gazteak eta lonjak}

\subsubsection{Lonjen presentzia udalean eta horiekiko ikuspegia}

Lonjen presentzia Trapagaranen azken 4-5 urteetan nabarmen handitu da. Egun, 13 lonja daude eta horiek herriaren erdigunean kokatuta daude. Esan daiteke, espazio horiek egun Trapagako gazte gehienen bizitzako parte direla, euren egunerokoaren parte garrantzitsu bilakatuz. Elkarrizketetan gazte lonjero batek aipatzen duen moduan "orain lonjak edozein izkinatan agertzen dira”.

Horien egoerari dagokionez, bai gazte lonjero, kulturako zinegotzi, hezitzaile eta komunitatearen agenteen ahotsetan, lonjen gaia nahiko normalizatuta dago. Nahiz eta batzuetan liskarrak ematen diren, batez ere, zaratarekin erlazioa duten gaiak agertzen direnean. Gehientan gaztetxogoak izan ohi dira, 15 urte inguru dituztenak, gai horrekin erlazionatzen direnak. Egoera horiek, auzokideen aldetik kexak ugaritzea ekarri du eta horri aurre egiteko asmoz udaletxeak ordenantza bat egitearen ideia planteatu du. Dena den, momentuz honen gauzapena alde batera utzi da, lonjak gazteak batzartzeko toki moduan ulertzen dutelako eta hauen itxierara heltzea nahi ez dutelako. Bitartean, bai bitartekari baita hezitzailearen laguntzarekin egoera hau normalizatzen saiatzen ari dira.

Gazteek lonjen inguruan ikuspegi nahiko ezkorra dagoela eta fenomeno horren inguruan komunitateak estereotipo negatibo asko dituela pentsatzen dute, espazio horien barnean egiten dutenaren inguruan mesfidantza erakutsiz. Gazte lonjeroek ikuspegi horiek lehenengo pertsonan bizitzen dituzte:

[...] todas las madres empiezan lo mismo, que si a ver qué haces ahí dentro, que si no sé qué, que no fumes, no bebas, que sé que éste fuma, que sé que éste bebe, a ver lo que haces tú... (G.M.22.).

Hala ere, nahiz lonjekiko ikuspegia oso baikorra ez dela pentsatzen den, talde eztabaidetan parte hartutako agente guztiek lonjen presentzia onartzen dute. Izan ere, konsziente baitira, Trapagazte proiektua salbu, herrian ez dela ekintza edo ekimen askorik eta, hortaz, ulergarri ikusten dute gazteek alternatiba desberdinak bilatzea horren aurrean. Baina alternatiba horiek errespetuan oinarritu behar direla diote komuntiateko agente desberdinek, eta elkarbizitza sustatu behar dutela. Hau da, bai auzokide baita komunitateko gainerako agenteekin erlazio egoki bat bideratzea ezinbestekoa dela, komunitatean dauden arauak errespetatuz. Horrez gain, nabaritzen dute gazteria haien lonjetan oso sartuta daudela gainerakoengandik baztertuz eta horren aurrean Trapagazte bezalako jarduera edo programa gehiago sortzea proposatzen dute, betiere, gazteen nahi eta beharrak kontuan hartuz.

\subsubsection{Lonjak zertarako?}

Gazte lonjeroentzat, lonjak batzartzeko leku bat izateaz gain, elkartzeko eta biltzeko aukera errezten die, euren lagunekin era intimoago batean egoteko aukera emanez eta haien arteko harremanak indartuz.

Significa un sitio de reunión donde puedo estar con mis amigos de toda la vida y donde pasar mis ratos libres para estar con ellos y divertirnos. Donde tienes tu propia intimidad (G.N.18.).

[...] es un punto de encuentro con tus amigos, porque muchas veces uno estudia fuera, el otro tal, pues quedas un momento o una tarde, va.... pues hoy, cena en la lonja. Y al final, te reúnes, y aunque uno esté en un lado y otro en otro estudiando, pues al final, te ves (G.M.22.).

Era berean, gazte horien arabera, espazio horietara joaten dira, besteak beste: eguraldi txarragatik, udalerrian gazteentzat dauden eskaintzak eskasak direlako, eta haien berdinekoekin modu intimoago batean erlazionatzeko.

Lonjak jarduera ezberdinak (afariak, festak...) burutzeko aukera emateaz gain parte-hartzea errazten duen erreminta bat direla ere diote. Azken finean, eta haiek aipatu bezala, Trapagaranen edozein 
ekintza burutzen denean lonjetara joaten dira horien berri emateko. Beraz, esan daiteke lonjak gazteekin komunikazioa bide moduan jokatzen dutela.

Aipatutakoez gain, lokal horietan ikaskuntza prozesu bat ematen da, hazkunde eta heldutasun maila bat emanez. Izan ere, gazteek hainbat erronkei aurre egin behar baitiete bai lonja topatzeko eta bai gero lonja bat mantendu ahal izateko egunerokoan dauden beharrei aurre egiteko: lonja bat bilatzeak eskatzen dituen ardurak, garbiketa txandak, konbibentzia arauak... . Horiez gain, espazio hori antolatu eta bertan konbibentzia eman ahal izateko, zein sortu ahal diren gaztazkei erantzun bat eman behar izateak, bizikidetza prozesu bat eskatzen du eta horrek era berean ikaskuntza prozesu aberats bat. Horrez gain, haien arteko harremanak asko indartzen dira ere:

Los lazos de amistad se han reforzado. [...] yo con ella antes, pues en clase nos llevábamos a matar [...] y ahora me llevo súper bien con ella (G.N1.18.).

Aprendemos convivencia. Te tienes que organizar para limpiar, para..., es que es para todo. Tiene que haber una organización (G.N2.18.).

Dena den, eta elkarrizketetan agertu den moduan, puntu honetan adinaren arabera iritzi ezberdinak agertu dira. Lonjero nagusien batek aipatzen duen moduan, "Yo creo que enseñarme no. Al final o sea lo que tú sabe lo llevas a la práctica, porque al final a ti te han enseñado a eso que cuando estás en un grupo tienes que respetar [...] no creo yo que te enseñe nada" (G.M.22.). Beraz, berarentzat lonja irakaskuntza elementu moduan jokatu beharrean bizitzan zehar ikasitakoa praktikan jartzeko baliabide moduan hautematen du.

Lonjaren barnean ez ezik, lonjatik kanpo ere ikaskuntza bat ematen da auzokideekiko erlazioei begira. Azkenean lonja komunitatearen beste etxebizitza bat da eta honek auzokideekin harremanetan egoteak eskatzen du.

[...] tener que ir a las reuniones de vecinos, comunidad, estar en relación con ellos [...] tú oyes a tus padres hablar de esas historias, pero nunca has ido a una reunión de vecinos, y al final, vas ahí y aprendes también algo nuevo (G.M.22.).

Horrez gain, eta arazoren bat ematen denean (orokorrean sortzen diren arazoak zaratarekin zerikusia daukate) bizikidetza egoki bat izateko akordioetara heldu behar dira haiekin komunikazio bat ezarriz.

\subsection{Lonjero Egunaren eta Trapagazte Programaren ebaluazioa}

Esan daiteke, 2007an sortutako Lonjero Egunak herriko gazteen arteko elkar ezagutza handitzeaz eta harreman sarea sortzeaz gain, elkarrekiko konfiantza indartu eta gazteen arteko giroa hobetu duela. Guzti horrek gazteriaren parte-hartzea handitzea lortu du ez soilik ospakizun honen prestaketan baizik eta herrian ospatzen diren beste ekimenetan ere (herriko jaien antolakuntza) kolektibo horren presentziaren igoera nabaritu da. Gainera, egun horren antolakuntzaren errespontsabilitatea gazteengan pasatu da haien parte-hartzea eta inplikazioa handituz. Eta ez hori bakarrik, baizik eta prozesu guzti horrekin ikaskuntza bat ere ematen da: mota honetako ekimenak prestatzeak eskatzen duten lana ikusiz.

[...] hacemos reuniones aquí, en el gaztetxe, y pues oye, vienen 203 de cada lonja y se dice. Nos juntamos 200 así (G.N.18).

Nosotras empezamos a venir a las reuniones, y ya a todas (G.N.18).

[...] al final, también en la reunión del [Día del] Lonjero ya vas viendo un poco la salsilla (G.N.18).

Trapagazte programan gazteek gogotsu parte hartzen dutela esan daiteke. Horren gauzapenarekin gazteek dituzten beharrak eta udaletxetik eskaintzen diren jarduerak haiengana heltzeko dauden zailtasunak detektatu dira. Programa horri esker, irtenbideak jartzen hasi dira emaitza positiboak lortuz. Alde batetik, eta gazteek dituzten beharrei dagokionez, proposatutako hainbat eskaera martxan jartzen hasi dira: gaztetxoko eta gaztegune baten sorkuntza. Lehenengoa 12-17 urte bitarteko gazteentzat zuzenduta dago, batez ere, adin hauetan gazteek leku propio falta izaten dutenez, haientzat leku bat izateko eta elkar harremanak sustatzeko. Bestalde, espazio horren sorkuntzarekin 15 urteko gazteek lonjetan duten presentzia gutxitzea lortu nahi dute gazte hauek komunitateetan sortzen ari diren arazoekin bukatzeko asmoz.
[...] entre semana, van a poder ir allí a hacer sus deberes [...], y luego, una zona más lúdica; están separados los espacios para que ellos se puedan interrelacionar. Pues ahí vamos a tener un futbolín, pimpón, pues unas Plays... [...] Pensamos que igual en ese espacio se pueda frenar ese bum que está habiendo ahora de chavalillos de 15 años en las lonjas, que son los que están dando problemas en las comunidades [...] (E.Z.).

Bigarrena, 17 urtetik gorako gazteengan zuzenduta dago eta hau, lonjetatik aparte, gazte guztiak elkarrekin egoteko leku bat izateko eskaerari erantzuten dio.

Aipatutako bi proiektu hauez gain, gazteen beharrak kontuan hartuta, skate park bat eraiki dute eta rokodromo bat eraikitzen ari dira. Lehengo honek, bai lonjeroak baita hezitzaile eta zinegotziak esan bezala, arrakasta handia izaten ari da ez soilik Trapagarango gazteengan, baizik eta inguruko herrietako gazteengan ere.

[...] la pidieron muchas lonjas y la verdad que ha tenido mucho éxito. Pero gente de Barcelona y todo que ha venido a la pista de skate (G.N2.18.). 
Aisiaz aparte, beste eremu batzuekin erlazioa daukaten behar ezberdinak agertu dira. Esaterako, enplegu agentziatik bideratzen zen informazioa ez zen gazteetara heltzen eta horren aurrean hezitzailea Whatsappa komunikazio bide moduan erabiltzen hasi zen gazteak informazio horren berri izateko. Hurrengo hezitzailearen hitzetan, ikusi ahal den bezala, horri esker, gazteak ikastaroetara joaten hasi dira.

Y este año, por ejemplo, a raíz de llevar todo esto me he involucrado más activamente con la agencia de empleo, porque me daba cuenta que no les llegaba las ofertas a los jóvenes. Y estuve en una de las excursiones, dándole vueltas... Claro, el medio de comunicación muchas veces es el WhatsApp con ellos. [...] hablé con A., de la agencia local, le dije... "si lo que ponéis en papel me lo haces llegar por WhatsApp, yo lo remito, y es una forma", y, pues oye, ha funcionado. [...] llevo un mes y medio. A. me ha estado mandando todo lo que ellos tienen en papel que no le llega a los chavales, porque lo dejas encima de la mesa o en el corcho que tenemos asignado para limpieza y fechas y horarios de visitas... (E.Hz.).

Beraz, ikusten da nola hezitzailearen presentzia, laguntza eta inplikazioa ez den soilik agertzen Trapagazte programaren inguruan hitz egiten denean, baizik eta zailtasunak agertzen diren bakoitzean bitartekari moduan jarduten saiatzen da, kasu honetan gertatzen den moduan, bi agente horien arteko komunikazioa erraztuz. Hezitzailearekin, zinegotziekin eta gazteekin egindako elkarrizketetan ikusi da nola Trapagazte programak eragin positiboa izan duen gazteengan. Azken finean, ikusten dute haien beharrak eta proposamenak adierazteko eta entzuteko aukera ematen ari zaiela. Eta ez hori bakarrik, baizik eta eskaera horiek aurrera eramaten direla. Gazte batek aipatzen duen moduan, “[...] al final nunca habíamos tenido actividades en el Valle y fue como... ¡bua, hay que aprovecharlas todas!" (G.N.18.).

Guzti horrek, aukera eman die gazteei haien artean gehiago ezagutzeko eta erlazionatzeko. Hau da, aurretik zegoen elkartasun hori indartzeko. Gainera, haien parte-hartzea ere igo dela esan daiteke ez soilik programa honetan parte-hartzen dutelako, baizik eta jada aipatu bezala, Trapagaranen ospatzen diren beste ekimenetan haien partaidetza ere ematen delako.

Dena den, programaren mugak ere detektatu dira. Hezitzaile eta zinegotziarekin egindako elkarrizketan atera den moduan, alde batetik, gazteak oraindik lonjetan oso sartuta daude eta horrek programarekiko aldentzea ekartzen du. Zinegotziak esan zuen moduan, “[...] creo que todavía la gente está muy en su lonja, si me interesa esta actividad voy y sino pues [...] ha habido actividades que se han quedado desiertas. Que dices [...] si la han propuesto ellos mismo y luego nadie viene. Sí que veo que ahí hay algo que todavía nos falla” (E.Z.). Bestetik, eta aurreko puntuetan aipatu den moduan, lonjarik ez dituzten gazteenganako hurbilpena ez da ematen baztertuak geratuz. Azken finean, eta lonjeroekin gertatzen ez den moduan, kolektiboaren parte horrek dituen beharrak eta proposamenak entzuteko aukera ez zaie ematen haien ahotsak desagerraraziz. Hezitzaileak aipatzen duen moduan:

[...] evidentemente, soy incapaz de llegar a todos los jóvenes, porque están muy distribuidos... Procuro pararme por sitios donde veo un grupo de jóvenes que sabes que obviamente no tiene la lonja, porque te los sueles encontrar en el mismo sitio y ya aprovechas, pero es diferente. No creas el mismo vínculo que cuando alguien tiene una lonja, que están acostumbrados a verte por allí (E.Hz.).

Programa honek dituen gabeziak ikusita, eta hezitzaileak eta zinegotziak aipatu bezala, etorkizunari begira erronka batzuk dituzte muga hauei aurre egin ahal izateko. Alde batetik, eta aurretik aipatu bezala, gazteak oraindik ere haien lonjetan oso sartuta daude. Hori dela eta, hutsune hori lantzen jarraitzearen beharra ikusten dute, hurrengo urterako gazteak lonjetatik gehiago ateratzeko zer egin ahal dutenaren inguruan hausnartzen jarraitu behar dutela diote. Bide horretan, lonjarik ez dituzten gazteengana heldu ahal izateko, jada aipatutako gazte guztietara zuzendua egongo den espazioa irekitzea izango da jomugetako bat. Horiez gain, detektatutako beste erronka bat da komunitatearen beste profesional batzuekin sare lana indartzea. Hain zuzen ere, Gizarte Hezkuntzako Eskuartze Programa Komunitarioaren hezitzaileaekin edota Ongizate Sozialarekin dagoen komunikazio handiagoa edukitzea azpimarratzen da.

\section{Ondorioak}

Ikerketa honen harira, ikusi ahal izan dugu lonjek leku garrantzitsu bat jokatzen dutela gazteen bizitzetan, gune horiek, euren denbora librearen parte handi bat okupatuz. Trapagarango herriko gazte gehienek espazio horiekin kontaktua daukate, beraz, esan daiteke erreferentziazko guneak direla haientzat.

Historian zehar gazteen partizipazio moduak aldatuz joan dira eta gaur egun Euskal Herrian lonjak esparru giltzarri bilakatzen dira gazteen asialdi esparruetan. Trapagaranen ere ikusi ahal izan dugu espazio horien garrantzia gazteen bizitzetan. Era bereean, lokal horiek parte-hartzeko oportunitate bat bilakatu dira, bertan gazteek protagonismo osoa hartzen dutelarik.

Gazteriak lonjetan askatasunez parte-hartzeko aukera aurkitzen dute. Hala, lonjetan egoteak autonomia bat izateko aukera eskaintzen die, eta gune bat autogestionatzeko aukera. Bertan, haiek dira benetako protagonistak, agintea dutenak. Zentzu honetan, eragiten eta interesatzen dieten gauzen inguruan erabakiak hartzeko askatasun osoa daukate. 
Lonjan festak antolatzean, afari, bazkari edota askari handi bat prestatzean, pelikula bat ikustean edota lokala dekoratzean, parte-hartzea ematen da. Gainera, eta haiek direnez antolakuntza guzti honetan errespontsabilitate guztia hartzen dutenak, konpromisoa, elkarlana eta inplikazioa ematen da, heldutasun bat hartuz, eta autonomoagoak bihurtuz. Beraz, ikaskuntza prozesu bat ematen da ere prozesu honetan zehar.

Dena den, eta komunitatearen inguruan hitz egitean, oraindik ere nabaritzen da gazteek arazoak izaten dituztela haien parte-hartzea posiblea egiteko. Besteak beste, kolektibo horren inguruan dauden aurreiritziak eta nagusien partetik gazteen ahotsak kontuan ez hartzeak, eragin zuzena daukalako parte hartze mugatu horretan. Trapagarango kasuan zentratuta, parte-hartzearen ildotik aurrerapen bat eman dela esan daiteke, eta komunitean subjektu pasiboak izatetik aktiboak izatera pasatu dira, haien ahotsak entzunak direla sentituz. Trapagazte programaren sorkuntzarekin gazteen parte-hartzea sustatzeaz gain, haien iritziak eta proposamenak entzuteko eta dituzten beharrak identifikatzeko aukera eman da, irtenbide eta alternatiba ezberdinak eskainiz. Guzti horretan, lonjak presentzia handia hartu dute, komunikazio bide moduan jokatzen dutelako eta, beraz, gune estrategiko bilakatu dira aipatutako prozesu hori posiblea eginez.

Programa horretan hezitzaileak presentzia eta garrantzia handia hartzen du gazteengan pieza giltzarri bilakatuz. Lonjeroekin asko inplikatzeaz gain berdintasunezko harreman estu bat sortzea lortu du, eta ahal duen guztietan bere laguntza eskaintzen du, ez soilik lonjaren barnean arazoren bat ematen denean, baizik eta aspektu pertsonaletan ere laguntzen saiatzen da. Horrez gain, instituzio eta gazteen artean bitartekari moduan ere jarduten du, horien arteko komunikazioa erraztuz. Gazte lonjeroek ere, hezitzaileak egiten duen lana eta esfortzua asko baloratzen dute, bere presentzia funtsezkoa bilakatuz.

Trapagarango kasuan, argi ikusi da, gazteen parte hartzea bultzatzeko, kasu honetan lonja testuinguruan mugitzen diren gazteena, bi logika osagarriak kontuan hartu behar direla. Alde batetik, Lonjero Egunean ikus daitekenez, gazteak protagonista bihurtzea ezinbesteko giltza da. Ekintzailetasunaz, parte-hartzeaz eta aktibazioaz hitz egiten badugu, ezinbestean gazteak inplikatu behar dira; era autonomo batean gaitasun eta aspektu horiek garatu ahal izateko. Beste alde batetik, erakundeetatik, kasu honetan, udaletxetik, lortu behar da gazteen presentzia eta parte-hartzea bultzatzea. Hori posiblea da, hezitzaileak eta proiektuak martxan jartzen badira. Proiektu horien helburuak izan behar lukete, beste batzuen artean: gazte parte-hartzea bultzatzea, beraien protagonismoa aldarrikatzea eta bitartekaritza lan bat aurrera eramatea. Baita, gazte politiketan gazteek paper garrantzitsu bat edukitzea ere: diseinuan, inplementazion eta ebaluazioan. Bi logika hauek, gazteen autogestioa eta erakundeek egiten duten lana, ez dute kontraesankorrak izan behar. Erronka da, ahal den neurrian, bion artean zubiak eraikitzea eta sinergiak aprobetxatzea.

Bukatzeko, aipatu beharko lirateke aztertutako Trapagazte programak ere badituela bere hutsuneak eta horiek etorkizunerako erronka bilakatu beharko lirateke. Hala, gazteen eta komunitatearen arteko elkar harremana sustatzen eta sendotzen jarraitzeko bide desberdin posibleak pentsatu beharko dira. Baina ezinbestekoa izango da, gazteen parte hartzeko bide horiek errazteko, euren ahotsa kontuan hartzea, eta prozesuan subjetu aktibo bihurtzea. Gazteak komunitatean parte har dezaten, lan honetan analizatutako ekimenak zein bestelakoak bideratu beharko dira, gizarte kohesionatuago eta inkusiboago bat lortzeko asmoz eta gazteak gizarteko eragile aktibo bihurtzeko. 


\section{Aipatutako bibliografia}

AMNISTIA INTERNAZIONALA (1996): La zanahoria. Manual de educación en derechos humanos para maestras y maestros de preescolar y primaria, Mexiko, Amnistia Internazionala.

AUBERT, A.; GARCIA, C.; eta RACIONERO, S. (2009): "El aprendizaje dialógico”, Cultura y Educación, 21. bol., 2. zbkia., 129-139 or.

CANADIAN MENTAL HEALTH ASSOCIATION (2003): Manual de participación juvenil: trabajando con jóvenes. Una guía para la participación juvenil en la toma de decisiones, Washington, Osasunaren Erakunde Panamerikarra.

CORCUERA, N; BILBAO, M; eta LONGO, O. (2013): Gazteen lonjak eta lokalak EAEn, Gasteiz, Eusko Jaurlaritzaren Argitalpen Zerbitzu Nagusia.

FLECHA, R; VARGAS, J; eta DÁVILA, A. (2012): “Metodología comunicativa crítica en la investigación en ciencias sociales: la investigación WORKALÓ”, Revista de Relaciones Laborales, 11. zbkia., 11-23 or.

FLICK, U. (2004): Introducción a la investigación cualitativa, Madril, Morata.

GIDDENS, A. (1995): Las consecuencias perversas de la modernidad: modernidad, contingencia y riesgo, Buenos Aires, Amorrortu.

GONZÁLEZ LÓPEZ, F. (2013): Jóvenes y participación. Estudio sobre participación juvenil, Gasteiz, Euskadiko Gazteriaren Kontseilua.

HABERMAS, J. (1987): Teoria de la acción comunicativa I. Racionalidad de la acción, Madril, Taurus.
LAESPADA, M. T. et al. (2008): Las lonjas: ¿una participación ciudadana efectiva? La experiencia de Portugalete, Bilbo, Deustuko Unibertsitatea.

QUINTANA, I. et al. (2013): Gazte Izaera: uso y gestión de espacios para la juventud en los municipios de Bizkaia, Bilbo, Bizkailab.

REVERTE, F. M. (2009): Ideas, preguntas y propuestas sobre la participación social en el ámbito de la juventud: asociacionismo, movimientos sociales, voluntariado y jóvenes no asociados, Madril, Espainiako Udalerrien eta Probintzien Federazioa.

RODRÍGUEZ GÓMEZ, G.; GIL FLORES, J.; eta GARCÍA JIMÉNEZ, E. (1996): Metodología de la investigación cualitativa, Malaga, Aljibre.

SUSTERRA FEDERAZIOA (2013): Programa Gazte Zabalik. Memoria de actuación [argitaragabea].

TEJERINA, B.; CARBAJO, D.; eta MARTÍNEZ, M. (2012): El fenómeno de las lonjas juveniles. Nuevos espacios de ocio y socialidad en Vitoria-Gasteiz, Gasteiz, Gasteizko Udala.

TRAPAGARANEKO UDALA / AYUNTAMIENTO DE TRÁPAGA (2013): Informe sobre el proceso de participación ciudadana en TrapaGAZTE!

- (2012): Conclusiones del proceso participativo en torno a las lonjas juveniles en Trápaga.

UNIVERSIDAD DEL PAÍS VASCO / EUSKAL HERRIKO UNIBERTSITATEA (2012): Atetik Atera. Zalla 2012. Proyecto de investigación acción participacion [rhttps://atetikatera.wordpress.com〉]. 